\title{
Tourist weather preferences in Europe's Arctic
}

\author{
Jens Kr. Steen Jacobsen ${ }^{1, *}$, Jon Martin Denstadli ${ }^{1}$, Martin Lohmann ${ }^{2}$, Eirik J. Førland ${ }^{3}$ \\ ${ }^{1}$ Institute of Transport Economics, Gaustadalléen 21, 0349 Oslo, Norway \\ ${ }^{2}$ Institut für Tourismus- und Bäderforschung in Nordeuropa, Fleethörn 23, 24103 Kiel, Germany \\ ${ }^{3}$ Climate Department, Norwegian Meteorological Institute, PO Box 43 Blindern, 0313 Oslo, Norway
}

\begin{abstract}
Numerous high-latitude locations in northern Scandinavia receive many summer vacationers, even though cool weather conditions there are at odds with some expert-based literature on tourist weather preferences. Surveys in 2 climatically different Arctic archipelagos demonstrate that most tourists perceive the summer weather as better than expected. However, weather preferences and tolerances deviate between high and low Arctic destinations, illuminating diverging and subjective ideas of what constitutes 'good', 'bad', and 'acceptable' weather. The study shows an overall preference for clear sky, in contrast to some earlier research emphasizing temperature as the most important tourism weather variable. Most tourists are indifferent to occasional rain, and a majority accepts frequently changing weather. Main dislikes are frequent rain and low visibility, the latter accentuating visual tourism aspects such as sightseeing.
\end{abstract}

KEY WORDS: Weather preference $\cdot$ Weather tolerance $\cdot$ Adverse weather $\cdot$ Tourism $\cdot$ Sightseeing . Outdoor recreation · Arctic

\section{INTRODUCTION}

Tourist destinations and their image are affected by weather conditions, which can influence tourists positively and negatively, but tourists' weather preferences and tolerances are underresearched (e.g. Perry 1993, 1997, Lise \& Tol 2002, Lohmann 2003, de Freitas et al. 2008a, Scott \& Lemieux 2010). Weather characteristics such as cold, heat, wind, precipitation, waves, fog, mist, and clouds may impact tourists' activities and wellbeing, and also have bearings on tourism operations (e.g. Scott et al. 2008). Weather might thus be perceived both as a resource and a limitation for tourism, depending on visitor interests and tolerances and types of tourism industry operations. Because perceptions of 'good' and 'bad' weather are subjective and context-dependent (e.g. Smith 1993), and because human climate thresholds are problematical to define (e.g. Meze-Hausken 2007, 2008), there is a lack of studies that empirically explore and compare tourists' weather preferences and tolerances in their actual destinations (de Freitas 2001, p. 16), particularly in contexts other than heliocentric beachoriented holidaymaking.

The importance of studying tourist weather tolerances and preferences is also underscored by global environmental change, as climate and weather in many areas are likely to shift, causing redistribution of climatic assets among tourism regions (Scott et al. 2004). Seemingly influenced by a research orientation emphasizing thermal comfort, some scientists have maintained that summer weather conditions in areas such as northern Europe at present are 'unfavourable' or 'poor' for tourism (e.g. Nicholls \& Amelung 2008). At the same time, it has been assumed that global climate change may lead to a shift of tourism demand to higher latitudes (e.g. Smith 1990, Scott et al. 2004, Hamilton et al. 2005, p. 263), creating additional opportunities for tourism in northern regions. However, high-latitude tourism as a general concept is imprecise, since it comprises destinations with various weather types in different climatic zones and with a diversity of visitor attractions and activities. This calls for comparative studies 
of tourist weather preferences and tolerances in different high latitude destination areas, both in the high Arctic, defined in terms of climate, and in other regions north of the Arctic Circle with non-Arctic summer weather conditions. Arctic weather aspects are also interesting in their own right, as weather conditions assumingly might pose challenges to the tourism and hospitality industries in such areas.

A general assumption is that visitors to areas such as the Arctic have fairly low expectations with respect to destination weather conditions and that their anticipations are likely to influence overall weather perceptions. Besides relying on information from friends and relatives, guidebooks are typical sources of information for prospective visitors (e.g. Jacobsen 2006, p. 20), assumingly also when it comes to climate and weather. For instance, the commonly used Rough Guide to Norway describes the main part of the summer season in the country, July and August, as the warmest period. Rain is a regular occurrence, it says, including a table showing that the northernmost part of Norway has less rainfall (in $\mathrm{mm}$ ) than other areas during these months (Lee 2009, p. 14-15). The German DuMont guidebook for Vesterålen (and the neighbouring archipelago of Lofoten) describes the summer weather in the region as cool with periods of rain. Moreover, it states that there is generally not much wind during the summer (Banck 1995, p. 19-20). This book also gives advice on clothing, emphasizing the importance of bringing a woollen pullover, raincoat, and windbreaker, but also shorts and swimwear (p. 219). In the Rough Guide, Svalbard is described as 'one of the most hostile places on earth' but with summer temperatures 'bobbing up into the late teens' (Lee 2009, p. 385). However, this book does not give any specific advice on clothing for summer tourists.

Since many people travel to high-latitude destinations in spite of unfavourable weather conditions, particularly in terms of thermal comfort, one would not expect Arctic tourists to be particularly weather sensitive but rather show fairly high acceptance for adverse weather and low temperatures. It might even be that particular tourist segments are attracted by cold climate and 'foul weather' and display preferences toward such conditions. It is not uncommon to seek out destinations that are perceived as marginal, where one imagines civilisation encounters nature, symbolising edges of the world (e.g. Jacobsen 1997, 2000, Cullen \& Pretes 2000) and where one can brave the elements and experience a sublime attractiveness of nature (e.g. Jacobsen 1994, Jasen 1997).
With a focus on summer season leisure travellers in the archipelagos of Vesterålen and Svalbard in Norway's Arctic, this study explores stated in situ weather preferences and tolerances among highlatitude tourists. Besides throwing light on some wider aspects of tourists' weather opinions, the following research questions are posed:

(1) How do tourists perceive weather conditions during their stay in high-latitude destinations, and do perceptions vary between high/low Arctic visitors?

(2) How tolerant are tourists to Arctic weather conditions, and do tourist weather tolerances vary between high and low Arctic destinations?

(3) What type of weather are Arctic tourists attracted by, and do weather preferences vary between, high/low Arctic visitors?

\section{REVIEW}

Besancenot (1989) assumes that ideal climate for tourism should provide basic levels of comfort, enjoyment, and safety (cited in Gómez-Martín 2006), but people nevertheless go on holiday tours to places where the climate is not seen as ideal. Still, climate as weather is one of the important factors influencing tourism attractiveness of many areas (e.g. Perry 1997, Lohmann \& Kaim 1999, Matzarakis 2006, de Freitas et al. 2008, Scott et al. 2008), and this is underscored by the fact that numerous people search out climate information when they plan their holiday tours (e.g. Perry 1997, Hamilton \& Lau 2006). However, relationships between weather and tourism have typically been assumed rather than empirically scrutinised, often ignoring that people travel to places both because of and despite weather conditions (e.g. Smith 1993, p. 398-399, Lohmann 2003, p. 320), for instance because of various types of place attachment. Many people also purposely visit areas with low temperatures and unpredictable weather conditions, if these locations are perceived as attractions (e.g. Jacobsen $1994,2000,2006$ ) or provide opportunities for specific activities such as recreational fishing and whale watching. Unstable weather in destination areas may influence tourist plans, decision-making and flexibility, for instance when intended open-air pursuits might be exchanged for indoor entertainment during unfavourable conditions (e.g. Smith 1993, p. 399, Denstadli et al. 2011).

Classically, research has differentiated between thermal, aesthetic, and physical impacts on tourists (de Freitas 1990, Matzarakis 2007, de Freitas et al. 2008a, Lin \& Matzarakis 2008, Zaninović \& Matzarakis 
2009). Thermal sensation refers to body-atmosphere energy balance, and it is thus dependent not only on solar radiation but also on temperature, wind, air humidity, peoples' physical activity, and clothing (e.g. de Freitas 1990). Aesthetic sensation has mostly referred to cloud cover, but horizontal and vertical visibility is also imperative to widespread tourism and holiday outdoor activities such as landscape sightseeing, boating, and hiking in rugged terrain. Physical sensation refers to temperature, air humidity, precipitation, and wind. Feelings such as warmth, coolness, humidity, precipitation (rain, sleet, snow), and windiness obviously affect tourists' use and perception of areas they visit, and such sensations thus influence traveller preferences and aversions. Nevertheless, feeling or braving the elements is pivotal in some types of al fresco tourism activities-also in the Arctic-and seems to be part of a trend labelled 'high touch' or 'polysensualism' (Naisbitt 1984, p. 52, Jacobsen 1994, p. 8). Arctic weather conditions such as low temperatures might also be a part of the appeal of outdoor adventure tourism (e.g. Gyimóthy \& Mykletun 2004). Moreover, the allure of tourism in northerly destinations with ice and snow might include sportsmanship and heroism (e.g. Spufford 1997).

Air temperature has regularly been considered the most influential climate variable for tourist wellbeing (e.g. Mieczkowski 1985, Lise \& Tol 2002, Bigano et al. 2006), emphasizing physical and thermal sensations of weather conditions rather than aesthetic aspects. This has been advanced by using the measure of physiological equivalent temperature as an indicator for impacts of climate change on thermal comfort of humans (Matzarakis \& Amelung 2008). Typical is a focus on 'cold stress'. Further, of the 5 elements composing Mieczkowski's (1985) pioneering Tourism Climate Index (TCI), 2 sub-indices describing daily temperature are given a weight of $50 \%$. Applications of tourism climate indexes have led to rather negative conclusions regarding tourism possibilities in northern Europe. An example is Nicholls \& Amelung (2008), basing themselves on Mieczkowski (1985), stating that conditions in most parts of Norway and Scotland during the summer months are 'unfavourable' or 'poor'. Corresponding conclusions are found in Hein et al. (2009). Both studies lack summer season data for areas north of the Arctic Circle, which presumably would have been characterised by even poorer conditions for tourism. In contrast, Scott et al. (2004) found that tourism in some of America's northernmost areas had among the highest summer season ratings, with a tourism climate index displaying excellent tourism condi- tions. However, most of these areas in North America are south of the Arctic Circle.

A central limitation of several climate indices for tourism is that they are expert-based (de Freitas et al. 2008b). Although climate indexes are grounded in general literature on weather, rating schemes for index components and variable weightings are based on author opinions (de Freitas 2003, de Freitas et al. 2008b, p. 400). Then again, 'poor weather' and 'good weather' are subjective and relative terms (e.g. Meze-Hausken 2007, 2008) that need to be empirically tested against traveller perceptions (e.g. Smith 1993), as weather preferences may vary among different types of destination (e.g. de Freitas 2001, Scott et al. 2008) and also among tourists. Few empirical studies in contexts other than beach holidays have encompassed travellers' stated weather preferences, tolerances, and dislikes.

For instance, research in precipitation-rich Scotland denotes unpleasant weather to be the single main reason for tourist dissatisfaction, and nearly $20 \%$ of overseas tourists and more than $10 \%$ of British visitors complained about the weather (Smith 1993, p. 400). These results provide some support for conclusions drawn from tourism climate index studies. However, if adverse weather does not persist over more than a few days, it may have limited effect on tourists and mainly result in substituting outdoor activities with indoor pursuits (e.g. Perry 1972). Limb \& Spellman (2001) found that British domestic tourists regarded rain as a natural risk and not necessarily a major negative experience.

One of the few broader surveys of tourists' weather preferences and dislikes indicates that sun and blue sky is an overarching favourite (Lohmann \& Kaim 1999). This study of German holidaymakers also reveals a majority preference for mostly warm weather, even if half of the respondents were indifferent to rather cool summer vacation weather and a majority would accept changeable weather. Moreover, most Germans showed indifference in relation to wind and an overwhelming dislike of frequent rain (Lohmann \& Kaim 1999). Results also indicated that tourists' prior beliefs regarding weather conditions were used to adjust weather perceptions. In line with expectancy-disconfirmation models of satisfaction (e.g. Oliver 2010), one can assume that high weather expectations are not confirmed (negative disconfirmation; i.e. weather experienced worse than expected, resulting in dissatisfaction), whereas low expectations when not confirmed tend to be of the positive disconfirmation type (i.e. weather being better than expected, resulting in satisfaction). Thus, for 
visitors to high latitude destinations, one would assume rather low expectations and, consequently, greater likelihood for positive disconfirmation.

Moreover, one should have in mind how variation in travel modes may affect weather exposure and thus impact on preferences and tolerances. For instance, motor tourism typically implies glancing at landscapes through the windows of a car and also landscape sightseeing from excursion boats gives tourists some shelter from precipitation and wind. Then again, weather conditions may influence holiday activities indirectly, such as wind leading to high waves and precipitation leading to slippery terrain, thus impacting quality and safety of some holiday pastimes. In areas such as the high Arctic, sea ice may influence operations of cruises and excursion boats.

\section{BACKGROUND}

The present study is based on 2 surveys in the northerly archipelagos of Vesterålen (north of the Arctic Circle, $68^{\circ}$ to $69^{\circ} \mathrm{N}$ ) and Svalbard $\left(74^{\circ}\right.$ to $81^{\circ} \mathrm{N}$, in the high Arctic). The Vesterålen Archipelago, with its mountainous and agricultural shores, fjords, sounds, and small fishing hamlets, includes landscapes appreciated by domestic and international tourists (e.g. Fyhri et al. 2009). The area also provides opportunities for whale-watching. Svalbard is called on for dramatic Arctic landscapes, such as snow-capped mountains by the sea, glaciers, and icebergs. But also wildlife, peculiar summer vegetation, and some of the world's northernmost settlements have tourism appeal (e.g. Viken 2006). July is by far the most popular month for tourism to the areas. This is partly a result of the holiday patterns in northern Europe and to some degree due to the appeal of the 'midnight sun', which when the skies are clear is fully visible all night in the northernmost part of Vesterålen from 22 May to 20 July and in the town of Longyearbyen in Svalbard from 20 April to 22 August (Fig. 1).

Compared to most other regions north of the Arctic Circle, there is relatively easy tourist access to most of the study areas. The greater part of summer season leisure trips to and within mainland northern Norway, including the archipelago of Vesterålen, is conducted by private car and motorhome/ camper. Among foreign visitors, coach travel is also a popular way of visiting. In Svalbard, most tourists arrive by air or by cruise ships. Typical visits include round trips with ships of various sizes along the shores of the archipelago. In 2008 foreign leisure travellers spent approximately 2.1 million nights in mainland northern Norway, while domestic vacationing encompassed just about 6.5 million guest nights (Dybedal 2009). In 2008 more than 40000 tourists arrived by air in Svalbard, while approximately 30000 came by ship, most of them during the summer season. The total number of guest nights in hotels in Longyearbyen was 89000 in 2008, while the number of guest nights on board cruise ships in Svalbard is not known (Statistics Norway 2009, p. 16).

Thanks to the influence of the Gulf Stream, many littoral areas in Norway north of the Arctic Circle have non-Arctic summer weather. The Arctic as a climatic zone includes only a small part of mainland Scandinavia, in northeastern Norway, while it encompasses all of Svalbard. Most of the coast and the outer parts of the fjords in the Vesterålen archipelago have a temperate climate in winter and seldom very hot weather in summer. However, daily maximum temperatures above $20^{\circ} \mathrm{C}$ are quite fre-

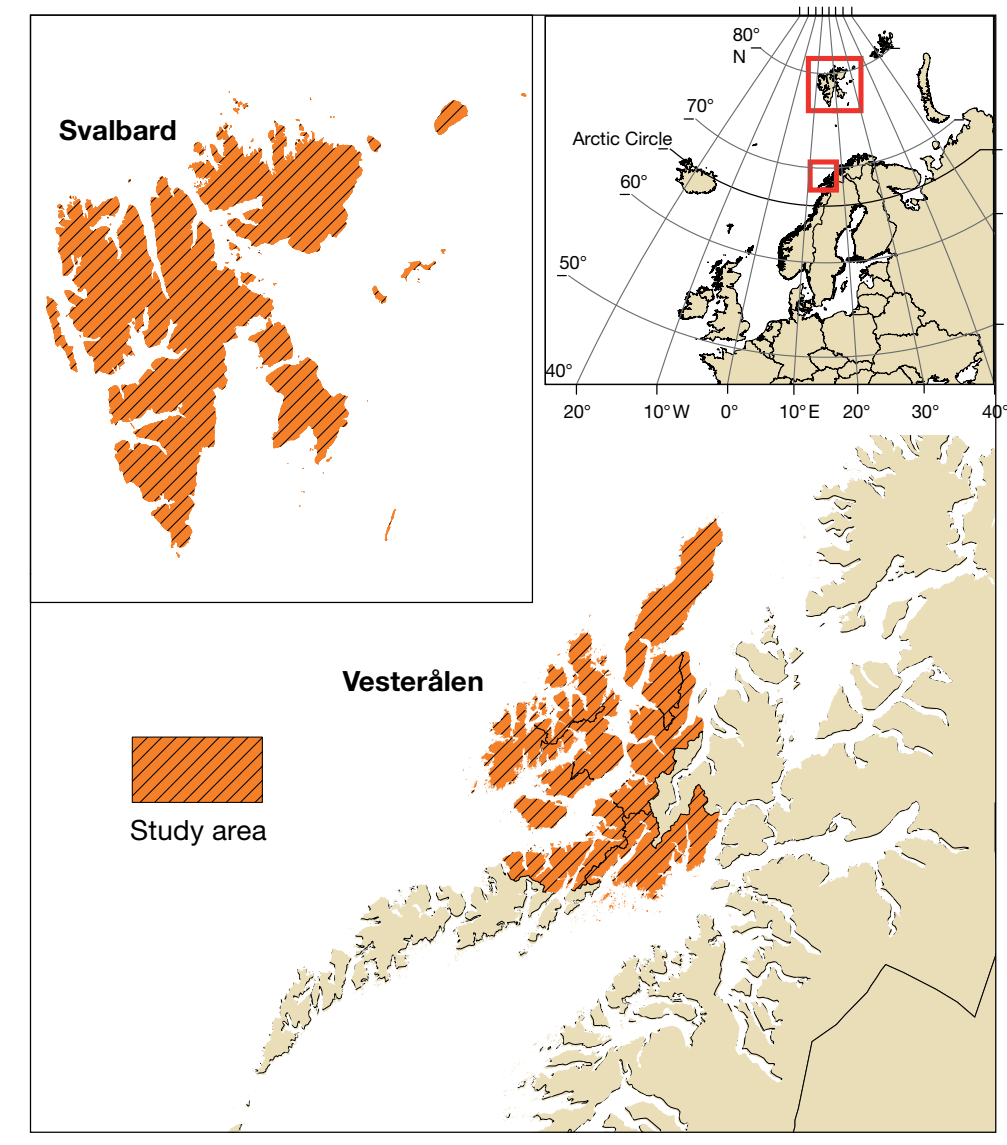

Fig. 1. Study areas 
quent during the summer peak season, when most tourism and leisure travel in northern Norway takes place. While Vesterålen and the littoral of most of northern Scandinavia on the whole have a relatively mild (sub-Arctic) climate, this is not the case for most other Arctic regions. In the Longyearbyen area in Svalbard, the average daytime temperature in July and August is about $8^{\circ} \mathrm{C}$, but temperatures well below $0^{\circ} \mathrm{C}$ may occur throughout the summer, and snowfall is not unusual. Occasionally, summer temperatures above $20^{\circ} \mathrm{C}$ have been recorded. Analysis of Arctic tourism in terms of weather also has to deal with the fact that there are great differences among Norway's northern littoral areas, and this also affects tourism.

Projected climate change effects of relevance to tourism in Norway's Arctic include an earlier spring and later autumn, increasing temperatures, more intense rainfall, melting glaciers, a shorter snow season, increasing sea levels and higher storm surges, and possibly more frequent high waves (ACIA 2005, Førland et al. 2009, Hanssen-Bauer et al. 2009). Some of these effects apply to the summer season and its length. In some areas, a warmer sea may have consequences for recreational anglers' catches. Moreover, increased occurrence of high waves and stronger wind might influence summer season activities such as sightseeing with smaller vessels, whale watching, and recreational sea angling from small boats. Additionally, probable changes in climate-related aspects such as visibility and low clouds might have an influence on hiking, sea angling, and landscape sightseeing. Moreover, high waves might lead to delays or cancellations of car ferry crossings and also leave recreational anglers on the shore. Fog and low clouds may lead to cancellations of flights. Air travel to and from Svalbard is particularly vulnerable because Longyear is the only airport in this archipelago.

\section{METHODS}

\subsection{Samples}

The populations in the present study are leisure travellers in the archipelagos of Vesterålen and Svalbard who do not live in the case areas. Previous research and transport statistics have shown that the majority of summer vacationers to Vesterålen arrive in their private cars or in coaches, while in Svalbard a majority of tourists arrive by air and many by cruise ships.
In order to reach the target population in Vesterålen, all passengers waiting for departure at 2 ferry landings in Andenes and Melbu were contacted on 6 days in each place, from 25 June to 6 August 2009. In Svalbard, a survey was conducted among departing passengers at the airport in Longyearbyen, on 12 days from 22 June to 10 August 2009. A screening question was first asked in order to identify passengers in the target category: non-resident leisure travellers. The potential respondents were then requested to fill in a self-guided questionnaire and return it to the survey staff. Given that cross-national, multicultural, and multilingual research necessitates special thoughtfulness (Manaster \& Havighurst 1972, Scheuch 1989), questionnaire formulations were tried out on various persons from different countries and discussed within the multilingual and multinational research team. The team could also draw on experiences from previous surveys of multilingual and cross-cultural audiences. The final questionnaire was translated from an English/German/Norwegian/Danish original by a professional translation company with extensive experience in translating social science surveys. The questionnaire was available in Dutch, English, French, German, Italian, Norwegian/Danish, Swedish, and Finnish (Vesterålen only). Most of the leisure travellers in the case areas have a good command of at least one of these languages. Tourists who visited Svalbard by cruise ship were partly included, as a considerable proportion of the outbound air passengers had participated in cruises.

In Vesterålen, 972 persons were identified as belonging to the target population. Of these, 101 declined to participate in the survey, and 24 questionnaires were later rejected because they were incompletely filled in, providing an effective sample size of 847. In Svalbard, 116 persons refused to contribute to the study, and 20 questionnaires were dispensed with because they were incompletely filled in, giving a sample size of 713 . The response rates are considered satisfactory (cf. Rideng \& Christensen 2004). As the target populations of the surveys are, strictly speaking, unknown, it is impossible to draw probability samples. The basis for survey planning was previous knowledge of traffic structure at the ferry crossings and at the airport. The chosen en route procedure, using ferry and airplane departures, generates a sampling error because the samples may not be perfect representations of the populations (Hurst 1994, Rideng \& Christensen 2004). However, by distributing data collection over a period of $6 \mathrm{wk}$ in Vesterålen and 7 wk in Svalbard and varying the days, these errors are reduced. 
A majority of the respondents were residing abroad; visitors from 37 different countries are represented in the samples (Table 1). In Vesterålen, $62 \%$ of the respondents were first-time visitors, compared to $88 \%$ in Svalbard. It is also worth noticing that a majority of the respondents hold a university or a college degree. Moreover, typical visitors are sightseers, as $98 \%$ in Svalbard and $61 \%$ in Vesterålen report to have participated in activities such as guided excursions and visits to museums and archaeological sites. Some $87 \%$ of the Svalbard tourists had been on a boat/ship excursion, compared to $30 \%$ of the Vesterålen visitors. In Vesterålen, many vacationers also pursue outdoor recreational activities such as salt water fishing and hiking. Every fourth visitor calls at friends/relatives during their stay in Vesterålen, while the same was the case for only $7 \%$ in Svalbard (Table 1).

\subsection{Measurement}

The main objective of the present study was to assess tourists and other leisure travellers' weather perceptions and preferences, including reactions to certain weather conditions in these 2 climatically different areas. Weather preferences were measured by asking interviewees to describe whether they would mainly like or dislike specific weather conditions on a possible future summer season trip to the case areas. Responses were given on a 3 point scale; 'I would like it', 'I would not care', and 'I would not like it'. The 8 elements considered were: 'clear sky', 'rather cool weather', 'windy', 'occasional rain', 'frequent rain', 'low visibility' (mist, fog, low clouds, etc.), 'high sea waves', and 'frequently changing weather'. The items consequently include elements related to thermal, aesthetic, and physical sensation.

In order to measure tolerance for unfavourable weather, the visitors were asked whether they mainly agreed or disagreed, on a 5 point scale, with 3 case area weather statements: 'I enjoy a visit to this area regardless of the weather is like'; 'I would not like to return to this area because of the bad weather conditions', and 'higher summer temperatures will make this area more interesting to me'. The interviewees were also asked if they had checked out the weather/ climate conditions for their destination(s) in northern Norway at home, before the decision to go on the present trip. Furthermore, the respondents were asked about their general perception of the weather during their stay ( 1 = 'very poor', 5 = 'very good'), and if the weather had been better or worse than ex-
Table 1. Respondent characteristics (\%)

\begin{tabular}{|c|c|c|}
\hline & Vesterålen & Svalbard \\
\hline \multicolumn{3}{|l|}{ Gender } \\
\hline Female & 50 & 50 \\
\hline Male & 50 & 50 \\
\hline \multicolumn{3}{|l|}{ Educational level } \\
\hline Primary school & 10 & 4 \\
\hline Secondary education & 36 & 22 \\
\hline University/college & 54 & 74 \\
\hline \multicolumn{3}{|l|}{ Age (yr) } \\
\hline Up to 39 & 29 & 27 \\
\hline 40 to 49 & 19 & 17 \\
\hline 50 to 59 & 26 & 18 \\
\hline 60 or older & 26 & 28 \\
\hline \multicolumn{3}{|l|}{ Country of residence } \\
\hline Norway & 46 & 18 \\
\hline Germany & 11 & 11 \\
\hline Sweden & 6 & 11 \\
\hline United Kingdom & - & 17 \\
\hline France & 4 & 9 \\
\hline Netherlands & 7 & 3 \\
\hline United States & - & 10 \\
\hline Switzerland & 4 & 4 \\
\hline Italy & 5 & 2 \\
\hline Other countries & 17 & 15 \\
\hline \multicolumn{3}{|l|}{ Experience with case area } \\
\hline First visit & 62 & 88 \\
\hline Visited before & 38 & 12 \\
\hline \multicolumn{3}{|c|}{ Activities (multiple answers possible) } \\
\hline Sightseeing & 61 & 98 \\
\hline Guided excursion with boat/ship & 30 & 87 \\
\hline Outdoor recreation & 44 & 24 \\
\hline Visit to friends/relatives & 25 & 7 \\
\hline
\end{tabular}

pected (on a 5 point disconfirmation scale where 'worse than expected' was at the one extreme with 'better than expected' at the other extreme). Also, the survey included questions regarding climate change and visitor assessments of possible higher future summer temperatures.

The items employed in the survey and the reply alternatives were selected partly on the basis of previous research (e.g. Lohmann \& Kaim 1999) in order to make comparisons possible. To some extent, the research design was also based on interviews in the areas 1 yr before the survey. The simplicity of most of the survey instruments was mainly a consequence of interview time constraints.

\section{RESULTS}

\subsection{Weather tolerances}

Weather statistics provided by the Norwegian Meteorological Institute (www.met.no) show that the weather in the case areas during the survey period 
Table 2. Weather statistics for case areas

\begin{tabular}{|c|c|c|c|c|c|c|c|}
\hline & \multirow{2}{*}{ Max. } & \multicolumn{3}{|c|}{ Temperature $\left({ }^{\circ} \mathrm{C}\right)$} & \multirow[b]{2}{*}{ Mean } & \multicolumn{2}{|c|}{$\longrightarrow$ Precipitation } \\
\hline & & Mean max. & Min. & Mean min. & & Total (mm) & No. of $\mathrm{d} \geq 1.0 \mathrm{~mm}$ \\
\hline \multicolumn{8}{|c|}{ Svalbard (Longyearbyen) } \\
\hline July 2009 & 14.8 & 10.0 & 1.0 & 5.7 & 7.7 & 7.1 & 3 \\
\hline 30 yr mean (July) & 14.2 & 9.0 & 1.7 & 4.8 & 6.4 & 16.3 & 5 \\
\hline \multicolumn{8}{|l|}{ Vesterålen } \\
\hline July 2009 & 23.4 & 16.5 & 6.2 & 10.5 & 13.3 & 15.8 & 5 \\
\hline 30 yr mean (July) & 23.3 & 15.7 & 4.7 & 9.5 & 12.5 & 56.0 & 10 \\
\hline
\end{tabular}

was characterised by minor precipitation and temperatures slightly higher than average (Table 2). Average daily maximum temperature in Vesterålen in July was $16.5^{\circ} \mathrm{C}$, and in Svalbard (Longyearbyen) it was $10.0^{\circ} \mathrm{C}$. Still, cold evenings/nights were observed with temperatures close to freezing in Svalbard and only $6.2^{\circ} \mathrm{C}$ in Vesterålen. In both areas, total precipitation was modest compared to normal rainfall in July, and the number of days with noticeable rain were 3 in Svalbard and 5 in Vesterålen. However, neither area normally experiences a great deal of rain during the summer season, with the average for July during the past $30 \mathrm{yr}$ being 55 and $16 \mathrm{~mm}$, respectively.

Results show that some $55 \%$ of the respondents had researched the weather/climate conditions for their destination(s) before the decision to go on the present trip, and this was more common among tourists in Svalbard than among those who visited Vesterålen (65 versus $47 \%$ ). Thus, weather consciousness increases here by destination latitude. Still, the fact that more than one-third of the Svalbard visitors and a majority of the tourists to Vesterålen did not seek out information on weather conditions suggests that many Arctic tourists are more or less unconcerned about the weather at their destination, even though a number of them might have weather and climate knowledge from organic sources such as the educational system and the news media.

Responses to the question 'How would you generally describe the weather during your visit to Vesterålen/Svalbard' in Table 3 show that more than $80 \%$ of the Svalbard visitors and close to $70 \%$ of those visiting Vesterålen found the weather to be fairly good or very good. In spite of average temperatures in the survey period being $6.5^{\circ} \mathrm{C}$ lower in Svalbard, tourists in the high Arctic perceived the weather as better than did the visitors in Vesterålen. Weather conditions in both destinations exceeded tourists' prior expectations. The frequency distribution of the disconfirmation measure shows that on the whole, $67 \%$ of the responses are above the neutral point (positive disconfirmation) and only $6 \%$ below (negative disconfirmation) - $76 \%$ of Svalbard visitors found the weather to be better than expected, compared to $58 \%$ of the Vesterålen tourists.

Some differences in relation to visitor provenance (home country) were revealed. Country of origin was categorized into 6 groups: (1) Norway, (2) other northern European countries, (3) central and eastern Europe, (4) southern Europe, (5) North America, and (6) rest of the world. A MANCOVA (Multivariate ANOVA) using the 2 statements as dependent variables and including temperature on the survey date as a covariate, shows a highly significant Wilks' $\lambda$ test for country of origin for both case areas $\left(F_{10,1404}=\right.$ 6.526, $\mathrm{p}<0.001$ and $\left.F_{10,1654}=2.937, \mathrm{p}=0.001\right)$. Univariate between-subject tests demonstrate that both independent variables are related to destination, with 2 significant findings: (1) Visitors from southern Europe perceived the weather as poorer and experienced less positive disconfirmation than did other nationalities.; and (2) tourists visiting from North America generally described weather conditions as better than other tourists, and, correspondingly, reported higher levels of positive disconfirmation.

Table 3. Responses to statements (\%) on weather perceptions

\begin{tabular}{|c|c|c|c|}
\hline & Svalbard & Vesterålen & Total \\
\hline \multicolumn{4}{|c|}{ General description of weather } \\
\hline Very poor & - & - & - \\
\hline Fairly poor & 3 & 6 & 4 \\
\hline Neither good nor bad & 11 & 25 & 19 \\
\hline Fairly good & 46 & 46 & 46 \\
\hline Very good & 39 & 23 & 30 \\
\hline Total & 100 & 100 & 100 \\
\hline \multicolumn{4}{|c|}{ Weather compared to expectations } \\
\hline Worse than expected & 1 & 3 & 2 \\
\hline 2 & 3 & 5 & 4 \\
\hline 3 & 19 & 34 & 27 \\
\hline 4 & 27 & 27 & 27 \\
\hline Better than expected & 49 & 31 & 39 \\
\hline Total & 100 & 100 & 100 \\
\hline
\end{tabular}


Table 4. Visitor responses to weather 'tolerance' statements (\%). Negative: 'I would not like to return to this area because of bad weather conditions'. Positive: 'I enjoy a visit to this area whatever the weather is like'. Mixed: 'Higher summer temperatures will make this area more interesting to me'

\begin{tabular}{|lcccc|}
\hline & & Negative & Positive & Mixed \\
\hline Agree & $(1)$ & 2 & 36 & 15 \\
& $(2)$ & 3 & 27 & 12 \\
Neither/nor & $(3)$ & 15 & 24 & 34 \\
& $(4)$ & 11 & 6 & 9 \\
Disagree & $(5)$ & 69 & 7 & 30 \\
Total & & 100 & 100 & 100 \\
\hline
\end{tabular}

Table 4 displays responses to the 'tolerance' statements. Firstly, $80 \%$ of visitors disagreed with the survey statement 'I would not like to return to this area because of the bad weather conditions'. However, a majority of the respondents states that the pleasure of the visit is independent of weather conditions; only $13 \%$ disagree with this statement. Also, a larger proportion of respondents disagree with the statement that higher summer temperatures will make the area more interesting than agree with it.

Taken together, results indicate that tourists to Arctic destinations have a fairly high tolerance for what regularly would be considered unfavourable weather conditions for a summer holiday tour. As for disconfirmation, differences across visitor segments (high/ low Arctic) emerge. A MANCOVA using the 3 'tolerance' statements as dependent variables and temperature on the survey day as covariate shows a highly significant Wilks' $\lambda$ test $\left(F_{3,1436}=80.232, \mathrm{p}<0.001\right)$. Univariate between-subject tests show that 2 of the independent variables (return intentions and higher summer temperatures) are related to destination $\left(F_{1,1438}=9.395, \mathrm{p}<0.010\right.$ and $F_{1,1438}=224.792, \mathrm{p}<$ 0.001 , respectively): inspection of mean scores displays that tourists to Svalbard express higher disagreement to these statements than do visitors to Vesterålen.

\subsection{Weather preferences}

Table 5 shows respondents' weather preferences on a possible future summer season trip to the case areas. The first 2 items are related to sky conditions (aesthetic elements in the typology of de Freitas et al. 2008a); the next 5 concern physical sensations; while the last item ('rather $\mathrm{Cool}^{\prime}$ ) represents an element of thermal sensation.

Looking first at the totals, the main finding is that a clear sky is generally preferred by $87 \%$ of the tourists, while $12 \%$ would not care, and only $1 \%$ would not like a clear sky. The foremost weather dislikes are frequent rain (87\%) and low visibility $(75 \%)$. A majority of $54 \%$ of the tourists would also not like high sea waves. On the other hand, some $60 \%$ would not care about frequently changing weather, and just as many are indifferent to rather low temperatures.

A factor analysis of weather preferences provides 2 distinct factors with eigenvalues of 2.579 and 1.106 , respectively, and $53 \%$ variance explained (the item 'high sea waves' was omitted due to double factor loadings).

Factor 1 comprises 'clear sky', 'low visibility', and 'frequent rain', and can be termed 'sky conditions'. The first 2 items are typical aesthetic elements of weather, whilst 'frequent rain' is supposedly related to physical sensations. However, frequent rain will also reduce horizontal visibility and hence lessen opportunities for landscape sightseeing and other activities dependent on viewing.

Factor 2, termed 'foul weather', includes 'frequently changing weather', 'windy', 'occasional rain', and 'rather cool'. The first 3 items represent physical sensations, while the last item refers to body-atmosphere energy balance (thermal sensation). All together, the 4 items express preferences/dislikes for weather conditions that were generally perceived as unfavourable in many previous studies.

Table 5. Visitor assessments of weather conditions on a future summer season trip to Vesterålen and Svalbard (\%)

\begin{tabular}{|c|c|c|c|c|c|c|c|c|c|}
\hline & $\begin{array}{r}\text { Wo } \\
\text { Vesterålen }\end{array}$ & $\begin{array}{l}\text { uld like it } \\
\text { Svalbard }\end{array}$ & Total & $\begin{array}{l}\text { Would } \\
\text { Vesterålen }\end{array}$ & $\begin{array}{l}\text { d not care } \\
\text { Svalbard }\end{array}$ & Total & $\begin{array}{r}\text { Woulc } \\
\text { Vesterålen }\end{array}$ & $\begin{array}{l}\text { d not like i } \\
\text { Svalbard }\end{array}$ & Total \\
\hline Clear sky & 88 & 86 & 87 & 11 & 14 & 12 & 1 & 1 & 1 \\
\hline Low visibility (mist, low clouds, etc.) & 2 & 3 & 2 & 19 & 27 & 23 & 79 & 70 & 75 \\
\hline Frequent rain & 2 & 2 & 2 & 9 & 13 & 11 & 89 & 86 & 87 \\
\hline Occasional rain & 3 & 3 & 3 & 69 & 68 & 69 & 28 & 29 & 28 \\
\hline Frequently changing weather & 4 & 5 & 5 & 56 & 67 & 61 & 40 & 28 & 34 \\
\hline Windy & 4 & 4 & 4 & 48 & 48 & 48 & 48 & 47 & 48 \\
\hline High sea waves & 8 & 5 & 6 & 44 & 36 & 40 & 49 & 59 & 54 \\
\hline Rather cool & 3 & 20 & 11 & 48 & 70 & 58 & 49 & 10 & 31 \\
\hline
\end{tabular}


Comparing mean values on the factor scores demonstrates a significant effect of destination on both variables. Univariate tests show that visitors to Svalbard are more likely to accept harsh weather conditions than are visitors to Vesterålen $\left(F_{1,1324}=\right.$ 77.983, p < 0.001), whilst Vesterålen tourists express greater preferences for clear skies $\left(F_{1,1324}=7.857, \mathrm{p}<\right.$ 0.010). Results in Table 4 show that differences are particularly evident for the temperature variable. In Svalbard, $20 \%$ of the tourists would actually prefer the weather to be rather cool, $70 \%$ would not care, and only $10 \%$ would not like it. In Vesterålen, only $3 \%$ of visitors would prefer cool weather. This might be understood in relation to the common tourist interest in experiencing snow and ice in the high Arctic.

\section{DISCUSSION AND CONCLUSIONS}

Gathering weather/climate information before the decision to go on the present tour was more common among tourists in Svalbard (65\%) than among those who visited Vesterålen (47\%). In comparison, 42\% of international German summer holidaymakers departing to all kinds of destinations from the Hamburg area had gathered destination climate information during the planning stage (Hamilton \& Lau 2006, p. 241), indicating that weather conditions are taken more into consideration when travelling to the high Arctic than to many other places.

We have demonstrated here that weather preferences partly deviate between high-latitude destination areas, illuminating that tourists have diverging and subjective ideas of what constitutes 'good', 'bad', and 'acceptable' weather in their travel contexts. The majority of tourists seemed to have some general knowledge of destination area weather before arrival. The large proportion of respondents who found the weather to be better than expected also suggests general tourist weather awareness. This further indicates that tourists to such Arctic regions generally have fairly low expectations (i.e. they expect rather low temperatures, wind, rain, etc.) with respect to destination weather conditions.

The fact that $80 \%$ of the respondents disagreed with the statement 'I would not like to return to this area because of the bad weather conditions' is in opposition to some earlier research, stating that conditions in most parts of Norway during the summer months at present are 'marginal' or even 'unfavourable' for general tourism activity (e.g. Nicholls \& Amelung 2008). By and large, findings agree with Scott et al. (2004), who reckoned the summer climate in America's northern areas to be favourable for tourism; these American areas are mostly south of the Arctic Circle, however, and thus farther south than Scandinavia's Arctic.

The present study shows an overall preference for clear sky $(87 \%)$, which stands in contrast to some earlier publications emphasizing temperature as the most important weather aspect (e.g. Mieczkowski 1985, Lise \& Tol 2002, Bigano et al. 2006). However, this finding corresponds with Lohmann \& Kaim (1999), who found that $85 \%$ of Germans would like the summer holiday weather to be 'often sunny, blue sky'. Also the results that only a minority of $41 \%$ of Svalbard tourists would like it to be rather warm on a possible future visit and that $20 \%$ would like it to be rather cool, contrast some of the tourism weather literature emphasizing comfortable temperature as crucial to tourist preferences. In Vesterålen, however, a considerable majority of the visitors (77\%) would like it to be rather warm on a possible future summer season trip to the area.

Only a small proportion of the travellers would like frequent rain, and $87 \%$ would dislike it, which is in accordance with Lohmann \& Kaim's study of preferences of German holidaymakers (1999, p. 58). The fact that there is a substantial dislike of low visibility among the visitors in Vesterålen and Svalbard emphasises the visual aspects of tourism (sightseeing) (e.g. Jacobsen 2001). Even if some expert-based attempts to develop tourism climate indexes have stated that they had sightseeing in mind (e.g. Mieczkowski 1985, p. 231), the wide scope of sightseeing types seems not to have been fully considered in previous literature, epitomised by, for instance, car travel and 'windshield wilderness' experiences (e.g. Jacobsen 2006, Louter 2006), as well as cruises.

The prevalent aversion towards high sea waves is more common in Svalbard (59\%) than in Vesterålen $(49 \%)$, most likely because an overwhelming majority of the tourists in the high Arctic Svalbard archipelago had been on boat/ship excursion, exposing them to possible rough seas, compared to only a minority of the Vesterålen visitors. Additionally, nearly half of the respondents (48\%) would not like it to be windy on a possible return to the area. This might be due to higher wind speeds and thus more severe wind-chill effects in Arctic destinations. In Svalbard, this might also be a consequence of the familiar general effect of wind on sea waves.

The overall tourist indifference to occasional rain revealed in these surveys is in line with Limb \& Spellman (2001) and Perry (1972), who stated that some rain is in many areas regarded as a natural risk 
and not necessarily a negative experience. Here, the results were nearly identical in Svalbard and Vesterålen. The lack of tourist concern for frequently changing weather might to be linked to what one might expect in areas such as Scandinavia's Arctic littoral. Acceptance for frequently changing weather $(61 \%)$ is at the same level as revealed among German summer holidaymakers $(60 \%)$ (Lohmann \& Kaim 1999, p. 58).

Therefore, weather should not be considered a major obstacle to tourism in high-latitude destination areas. At the same time, it is evident that people mostly do not travel to the littoral of northern Scandinavia (i.e. Vesterålen) to enjoy warm summer weather even if they might hope for sunny days. What one sees here is rather an acceptance of most weather conditions - except frequent rain and low visibility, and, for visitors exposed to the risk of rough seas, also high waves. However, destination managers should consider that a small segment of the high Arctic tourists actually seem to prefer rough weather conditions and develop activities targeted toward this category.

Nonetheless, Arctic tourists' weather expectations are not congruent with the actual weather conditions at the destination. In general, visitors expect the weather to be worse than it actually is, despite the fact that many seek out weather information before they make the decision to go to Arctic Norway. Although the survey period was characterised by relatively nice weather, temperatures were only slightly above the $30 \mathrm{yr}$ average $\left(0.8^{\circ}\right.$ and $1.0^{\circ} \mathrm{C}$ for Vesterålen and Svalbard, respectively). Even so, the large majority of respondents expressed positive disconfirmation (i.e. weather being better than expected). Thus, destination managers should work to increase tourists' knowledge about weather conditions in high latitude destinations (e.g. Matzarakis 2006, Zaninović \& Matzarakis 2009). Many prospective visitors may have too negative perceptions of weather conditions in high-latitude regions, preventing these destinations from entering people's consideration when holiday decisions are made. Given the projections for an earlier spring and a later autumn in Norway's Arctic, improved and updated climate information for tourists might also contribute to prolongation of the main season, even if seasonal holiday patterns predominantly are subject to slow change (e.g. Haukeland \& Jacobsen 1994).

Both in Vesterålen and Svalbard, the weather was characterised by minor precipitation compared to the $30 \mathrm{yr}$ average for the study period, and this might have affected respondents' responses to the state- ments concerning weather tolerance and preferences. Also, due to interview time constraints, the questionnaire was kept simple and more multi-item measures for some variables (e.g. disconfirmation, weather tolerance) would have increased validity of results.

To develop regionally applicable tourism climate indexes in situations other than heliocentric beach vacations, it would be necessary to conduct multidimensional studies, including area-specific weather preferences, tolerances, and dislikes, connected to the commonly wide scope of traveller motives and activities. Up to the end of the 2000s, most tourism climate indexes have been too general and have not related appositely to highly subjective and context-specific tourist weather perceptions, interests, and tolerances. For instance, Besancenot (1989) argued that in tourism climatology, the amount of rain in a day has only secondary interest compared to ways in which rain falls, frequencies of showers, duration of downpours, and the time of day when they occur (in Gómez-Martín 2006). The same goes for clear sky, and during the Arctic summer, a clear sky at midnight is important, due to the tourist interest in the midnight sun.

More detailed research on tourist weather responsiveness is also interesting in its own right, particularly in relation to specific outdoor activities, also in non-Arctic destinations area. In addition, pre-trip weather perception effects on destination/route decisions might be noteworthy for impending studies, particularly in relation to high-latitude destinations, since results from the present study suggest that many tourists expect the weather in such areas to be worse than it actually is. Tourist perceptions and assessments of weather information in destination marketing and guidebooks might be yet another central topic requiring further scrutiny.

Acknowledgements. The study was funded by the Research Council of Norway (Climate change and impacts in Norway-NORKLIMA). The authors thank the anonymous reviewers for helpful comments and Bente Heimtun for contributing to the survey design.

\section{LITERATURE CITED}

ACIA (2005) Arctic climate impact assessment (ACIA). Cambridge University Press, Cambridge

Banck C (1995) Lofoten Vesterålen. DuMont, Cologne

Besancenot JP (1989) Climat et tourisme. Masson, Paris

> Bigano A, Hamilton JM, Tol RSJ (2006) The impact of climate on destination choice. Clim Change 76:389-406

Cullen BT, Pretes M (2000) The meaning of marginality: 
interpretations and perceptions in social science. Soc Sci J 37:215-229

de Freitas CR (1990) Recreation climate assessment. Int J Climatol 10:89-103

de Freitas CR (2001) Theory, concepts and methods in tourism climate research. In: Matzarakis A, de Freitas CR (eds) Proc 1st Int Workshop on climate, tourism and recreation. International Society of Biometeorology, Commission on Climate Tourism and Recreation, p 3-20. Downloaded from http://www.urbanclimate.net/cctr/ws/ papers/full_report.pdf

de Freitas CR (2003) Tourism climatology: evaluating environmental information for decision making and business planning in the recreation and tourism sector. Int J Biometeorol 48:45-54

de Freitas CR, Matzarakis A, Scott D (2008a) Climate, tourism and recreation: research progress a decade on. In Matzarakis A, de Freitas CR, Scott D (eds) Developments in tourism climatology. Ber Meteorol Inst Universität Freiburg, Vol 17, p 5-13

de Freitas CR, Scott D, McBoyle G (2008b) A second generation climate index for tourism (CIT): specification and verification. Int J Biometeorol 52:399-407

Denstadli J, Jacobsen JKS, Lohmann M (2011) Tourist perceptions of summer weather in Scandinavia. Ann Tourism Res 38:920-940

Dybedal P (2009) Fylkesvise økonomiske ringvirkninger av reiseliv i Nord-Norge og Trøndelag 2008 [Economic impacts of tourism in northern Norway and Trøndelag 2008]. Institute of Transport Economics, Oslo

Førland EJ, Benestad RE, Flatøy F, Hanssen-Bauer I and others (2009) Climate development in north Norway and the Svalbard region during 1900-2100. Rep Ser no. 128. Norwegian Polar Institute, Tromsø

Fyhri A, Jacobsen JKS, Tømmervik H (2009) Tourists' landscape perceptions and preferences in a Scandinavian coastal region. Landsc Urban Plan 91:202-211

Gómez Martín MB (2005) Weather, climate and tourism: a geographical perspective. Ann Tourism Res 32:571-591

Gómez Martín MB (2006) Climate potential and tourist demand in Catalonia (Spain) during the summer season. Clim Res 32:75-87

Gyimóthy S, Mykletun RJ (2004) Play in adventure tourism: the case of Arctic trekking. Ann Tourism Res 31:855-878

Hamilton JM, Lau MA (2006) The role of climate information in tourist destination choice decision making. In: Gössling S, Hall CM (eds) Tourism and global environmental change. Routledge, New York, NY, p 229-250

Hamilton JM, Maddison DJ, Tol RSJ (2005) Climate change and international tourism: a simulation study. Global Environ Change A 15:253-266

Hanssen-Bauer I, Drange H, Førland EJ, Roald LA and others (2009) Klima i Norge 2100: bakgrunnsmateriale til NOU Klimatilpassing [Climate in Norway 2100]. Norsk klimasenter, Oslo

Haukeland JV, Jacobsen JKS (1994) Staggering of holidays and extension of the holiday season: EU project in the plan of action for tourism: Norwegian conditions and experiences. Institute of Transport Economics, Oslo

Hein L, Metzger MJ, Moreno A (2009) Potential impacts of climate change on tourism: a case study for Spain. Curr Opinion Environ Sustainabil 1:170-178

Hurst F (1994) En route surveys. In: Ritchie JRB, Goeldner CR (eds) Travel, tourism, and hospitality research. Wiley, New York, NY, p 453-472
Jacobsen JKS (1994) Arctic tourism and global tourism trends. Res Rep 37, Lakehead University, Centre for Northern Studies, Thunder Bay, Ontario

$>$ Jacobsen JKS (1997) The making of an attraction: the case of North Cape. Ann Tourism Res 24:341-356

Jacobsen JKS (2000) Tourist perceptions of the ultimate European periphery. In: Brown F, Hall D (eds) Tourism in peripheral areas. Channel View, Clevedon, p 74-90

> Jacobsen JKS (2001) Nomadic tourism and fleeting place encounters: exploring different aspects of sightseeing. Scand J Hosp Tourism 1:99-112

Jacobsen JKS (2006) Reiser i unike landskaper: opplevelser og vurderinger av nasjonale turistveger [Journeys through unique landscapes: experiences and assessments of national scenic roads]. Institute of Transport Economics, Oslo

Jasen P (1997) Wild things: nature, culture and tourism in Ontario, 1790-1914. University of Toronto Press, Toronto

Lee P (2009) The Rough Guide to Norway, 5th edn. Rough Guides, London

Limb M, Spellman G (2001) Evaluating domestic tourists' attitudes to British weather: a qualitative approach. In: Matzarakis A, de Freitas CR (eds) Proc 1st Int Workshop on climate, tourism and recreation. International Society of Biometeorology, Commission on Climate Tourism and Recreation, p 21-34. Downloaded from http://www. urbanclimate.net/cctr/ws/papers/full_report.pdf

> Lin TP, Matzarakis A (2008) Tourism climate and thermal comfort in Sun Moon Lake, Taiwan. Int J Biometeorol 52:281-290

Lise W, Tol RSJ (2002) Impact of climate on tourist demand. Clim Change 55:429-449

Lohmann M (2003) Über die Rolle des Wetters bei Urlaubsreiseentscheidungen. In: Bieger T, Laesser C (eds) Jahrbuch der schweizerischen Tourismuswirtschaft 2002/2003. Institut für Öffentliche Dienstleistungen und Tourismus, Universität St. Gallen, St. Gallen, p 311-326

> Lohmann M, Kaim E (1999) Weather and holiday destination preferences: image, attitude and experience. Rev Tourisme 54:54-64

Louter D (2006) Windshield wilderness: cars, roads, and nature in Washington's national parks. University of Washington Press, Seattle, WA

Manaster GJ, Havighurst RJ (1972) Cross-national research: social-psychological methods and problems. Houghton Mifflin, Boston, MA

Matzarakis A (2006) Weather- and climate-related information for tourism. Tourism Hospital Plan Developm 3: 99-115

Matzarakis A, Amelung B (2008) Physiological equivalent temperature as indicator for impacts of climate change on thermal comfort of humans. In: Thomson MC, GarciaHerrera R, Beniston M (eds) Seasonal forecasts, climatic change and human health. Springer, Dordrecht, p 161-172

Meze-Hausken E (2007) Grasping climate perceptions as an issue of measuring climate impacts on society. Int $\mathrm{J}$ Biometeorol 52:1-2

Meze-Hausken E (2008) On the (im-)possibilities of defining human climate thresholds. Clim Change 89:299-324

> Mieczkowski Z (1985) The tourism climatic index: a method of evaluating world climates for tourism. Can Geogr 29: 220-233

Naisbitt J (1984) Megatrends. Futura, London

> Nicholls S, Amelung B (2008) Climate change and tourism in 
northwestern Europe: impacts and adaptation. Tourism Analysis 13:21-31

Oliver RL (2010) Satisfaction: a behavioral perspective on the consumer, 2nd edn. M.E. Sharp, New York, NY

Perry A (1972) Weather, climate and tourism. Weather 27:199-203

Perry A (1993) Weather and climate information for the package holiday maker. Weather 48:410-414

Perry A (1997) Recreation and tourism. In: Thompson RD, Perry A (eds) Applied climatology: principles and practice. Routledge, London, p 240-248

Rideng A, Christensen P (2004) En route surveys. Scand J Hosp Tourism 4:242-258

Scheuch EK (1989) Theoretical implications of comparative survey research: why the wheel of cross-cultural methodology keeps on being reinvented. Int Sociol 4: 147-167

Scott D, Lemieux C (2010) Weather and climate information for tourism. Proc Environ Sci 1:146-183

Scott D, McBoyle G, Schwartzentruber M (2004) Climate

Editorial responsibility: Helmut Mayer,

Freiburg, Germany change and the distribution of climatic resources for tourism in North America. Clim Res 27:105-117

Scott D, Gössling S, de Freitas CR (2008) Preferred climates for tourism: case studies from Canada, New Zealand and Sweden. Clim Res 38:61-73

Smith K (1990) Tourism and climate change. Land Use Planning 7:176-180

Smith K (1993) The influence of weather and climate on recreation and tourism. Weather 48:398-404

Spufford F (1997) I may be some time: ice and the English imagination. Picador, New York, NY

Statistics Norway (2009) Dette er Svalbard: hva tallene forteller [This is Svalbard]. Statistics Norway, Oslo

Viken A (2006) Svalbard, Norway. In: Baldacchino G (ed) Extreme tourism: lessons from the world's cold water islands. Elsevier, Amsterdam, p 129-144

Zaninović K, Matzarakis A (2009) The bioclimatological leaflet as a means conveying climatological information to tourists and the tourism industry. Int $\mathrm{J}$ Biometeorol 53:369-374

Submitted: March 17, 2011; Accepted: July 12, 2011

Proofs received from author(s): November 24, 2011 